\title{
Molecular detection of Hepatozoon canis and Babesia canis vogeli in domestic dogs from Cuiabá, Brazil
}

\author{
Detecção molecular de Hepatozoon canis e Babesia canis vogeli em cães domésticos de Cuiabá, Brasil \\ Mariana Granziera Spolidorio ${ }^{1}$; Mariana de Medeiros Torres²; Wilma Neres da Silva Campos²; Andréia Lima Tomé Melo²; \\ Michelle Igarashi ${ }^{3}$; Alexandre Mendes Amude ${ }^{3}$; Marcelo Bahia Labruna ${ }^{1}$; Daniel Moura Aguiar ${ }^{4 *}$ \\ ${ }^{1}$ Departamento de Medicina Veterinária Preventiva e Saúde Animal, Universidade de São Paulo - USP \\ ${ }^{2}$ Programa de Pós-Graduação em Ciências Veterinárias, Universidade Federal de Mato Grosso - UFMT \\ ${ }^{3}$ Curso de Medicina Veterinária, Universidade de Cuiabá - UNIC \\ ${ }^{4}$ Departamento de Clínica Médica Veterinária, Universidade Federal de Mato Grosso - UFMT
}

Received October 29, 2010

Accepted February 1, 2011

\begin{abstract}
The objective of this study was to report for the first time infection by Hepatozoon spp. and Babesia spp. in 10 dogs from the city of Cuiabá, State of Mato Grosso, central-western Brazil. A pair of primers that amplifies a $574 \mathrm{bp}$ fragment of the 18S rRNA of Hepatozoon spp., and a pair of primers that amplifies a 551 bp fragment of the gene 18S rRNA for Babesia spp. were used. Six dogs were positive for Babesia spp., and 9 were positive for Hepatozoon spp. Co-infection of Babesia spp. and Hepatozoon spp. was seen in 5 dogs. Sequenced samples revealed $100 \%$ identity with B. canis vogeli, and H. canis. This is the first molecular detection of H. canis in domestic dogs from Cuiabá. Additionally, it is described for the first time the presence of $B$. canis vogeli circulating among dogs in Cuiabá.
\end{abstract}

Keywords: Hepatozoon canis, Babesia canis vogeli, dogs, Mato Grosso, Brazil.

\section{Resumo}

O objetivo deste estudo foi relatar pela primeira vez a infecção por Hepatozoon spp. e Babesia spp. em cães domésticos provenientes da cidade de Cuiabá, estado de Mato Grosso. Foram utilizados pares de primers que amplificam um fragmento de 574 pb do gene $18 \mathrm{~S}$ rRNA de Hepatozoon spp., e 551 pb do gene 18S rRNA para Babesia spp. Dos 10 cáes amostrados, 6 apresentaram-se positivos para Babesia spp., e 9 foram positivos para Hepatozoon spp. pela PCR. Co-infecção entre Babesia spp. e Hepatozoon spp. ocorreu em 5 cáes. As amostras revelaram 100\% de identidade com B. canis vogeli, e as amostras que foram positivas para Hepatozoon spp. foram $100 \%$ idênticas a $H$. canis. Esta é a primeira identificação molecular de $H$. canis em cães domésticos em Cuiabá. Adicionalmente, descrevemos pela primeira vez a presença de $B$. canis vogeli circulando entre cáes em Cuiabá.

Palavras-chave: Hepatozoon canis, Babesia canis vogeli, cães, Mato Grosso, Brasil.

Hepatozoon species known to infect dogs are tick-borne protozoans transmitted through the ingestion of infected ticks that cause disease in dogs throughout the world. This infection is easily misdiagnosed by veterinarians as general symptoms are similar to those seen in other tick-borne diseases such as ehrlichiosis and babesiosis (McCULLY et al., 1975; MURATA et al., 1991). Similar clinical and hematological findings for canine hepatozoonosis

*Corresponding author: Daniel Moura Aguiar

Departamento de Clínica Medica Veterinária,

Universidade Federal de Mato Grosso - UFMT,

Av. Fernando Corrêa da Costa 2.367, CEP 78060-900, Cuiabá - MT, Brazil;

e-mail: danmoura@ufmt.br and babesiosis include fever, lethargy, anorexia, weight loss, anemia, neutrophilia and thrombocytopenia (GREENE et al., 2006). Two Hepatozoon species have been described in dogs, H. canis (RUBINI et al., 2005; PALUDO et al., 2005) and $H$. americanum (BANETH et al., 2000); the former is responsible for all Brazilian cases reported in domestic dogs, and the latter is responsible for North American cases. Recently, new genotypes of Hepatozoon spp. including one closely related to $H$. americanum were identified in wild carnivores from Brazil (ANDRÉ et al., 2010). While Rhipicephalus sanguineus has been incriminated as a vehicle in the transmission of $H$. canis (SPOLIDORIO et al., 2009), other studies have found evidence that Amblyomma ovale is 
a natural vector as this tick has been found to be naturally infected by $H$. canis, and able to acquire and transmit $H$. canis to dogs (FORLANO et al., 2005; RUBINI et al., 2009). Rhipicephalus sanguineus is the most common ixodid tick in urban areas in Brazil, and is also responsible for the transmission of Babesia sp. in dogs (LABRUNA; PEREIRA, 2001). In Brazil two Babesia species infecting dogs have been reported, B. canis vogeli (PASSOS et al., 2005) and B. gibsoni (TRAPP et al., 2006). However, in the city of Cuiabá, State of Mato Grosso, central-western Brazil, species of Hepatozoon sp. and Babesia sp. have not yet been reported in domestic dogs.

The objective of this study was to report the first molecular characterization of Hepatozoon spp. and Babesia spp. in 10 domestic dogs from the city of Cuiabá, Mato Grosso, seen at two university veterinary hospitals (Universidade Federal de Mato Grosso and Universidade de Cuiabá), between July and December 2009. They presented different symptoms and were diagnosed with Babesia sp. and/or Hepatozoon sp. infection by direct visualization of parasites in Giemsa-stained blood smears.

Blood samples from these dogs were collected in EDTA anticoagulant tubes, and kept frozen at $-20{ }^{\circ} \mathrm{C}$ until DNA extraction. DNA was extracted from each blood sample using the DNeasy Blood \& Tissue Kit (QIAGEN, Hilden, Germany), according to the manufacturer's instructions, and eluted in $100 \mu \mathrm{L}$ of TE buffer, provided by the same DNA extraction kit. Five microliters of extracted DNA were used for polymerase chain reaction (PCR) amplification. DNAse-free water was used as a negative control for DNA extractions and PCR assays. Primers HEP144-169 (5'-GGTAATTCTAGAGCTAATA-3') and HEP743-718 (5'-ACAATAAAGTAAAAAACA-3'), which amplify a 574-bp fragment of the $18 \mathrm{~S}$ rRNA of Hepatozoon spp., and primers BAB143-167 (5'-CCGTGCTAATTGTAGGGCTAATACA-3') and
BAB694-667(5'-GCTTGAAACACTCTARTTTCTCAAAG-3'), which amplify a 551-bp fragment of the gene $18 \mathrm{~S}$ rRNA of Babesia spp., were used according to Almeida (2011). PCRs were carried out in a total of $50 \mu \mathrm{L}$ water-solution containing $1 \mathrm{x}$ PCR buffer, $1.5 \mathrm{mM} \mathrm{MgCl} 2,0.2 \mathrm{mM}$ dNTPs, $1 \mathrm{U}$ of Platinum Taq DNA Polymerase (Invitrogen, Carlsbad, CA), and $0.2 \mathrm{mM}$ of each primer. PCR cycle conditions for Hepatozoon spp. consisted of a initial denaturation for 5 minutes at $95^{\circ} \mathrm{C}$, and 35 repetitive cycles of 30 seconds at $95^{\circ} \mathrm{C}, 30$ seconds at $50^{\circ} \mathrm{C}$, and 60 seconds at $72^{\circ} \mathrm{C}$, followed by a 5 minutes final extension at $72^{\circ} \mathrm{C}$. PCR cycle conditions for Babesia spp. primers consisted of a initial denaturation for 5 minutes at $95^{\circ} \mathrm{C}$, and 35 repetitive cycles of 30 seconds at $95^{\circ} \mathrm{C}, 30$ seconds at $58^{\circ} \mathrm{C}$, and 30 seconds at $72^{\circ} \mathrm{C}$, followed by a 7 minutes final extension at $72^{\circ} \mathrm{C}$. PCR products were electrophoresed through a 1.5\% agarose gel (Invitrogen, Carlsbad, $\mathrm{CA}$ ), stained with ethidium bromide (AMRESCO, Solon, $\mathrm{OH}$ ), and examined by UV transillumination. Amplicons of the expected size were purified with ExoSap (GE Healthcare Pittsburgh, PA) and sequenced in an automatic sequencer (Applied Biosystems/ PerkinElmer, model ABI Prism 310 Genetic, Foster City, CA) according to the manufacturer's protocol. Partial sequences obtained were submitted to BLAST analysis (ALTSCHUL et al., 1990) to determine the closest similarities to corresponding sequences.

From the 10 canine samples examined, 6 yielded amplicons through the PCR for Babesia spp., and 9 through the PCR for Hepatozoon spp. Five dogs presented amplicons by both PCR protocols, indicating co-infection by Babesia sp. and Hepatozoon sp., which was confirmed by DNA sequencing in at least three of these dogs (Table 1). With the exception of 3 positive samples (that showed a weak positive signal), all PCR products were DNA-sequenced. By BLAST analysis, the sequences obtained from the Babesia-PCR showed to be $100 \%$ identical to available

Table 1. Results of PCR and sequencing of Hepatozoon canis and Babesia canis vogeli in 10 dogs seen at two university veterinary hospitals in the city of Cuiabá, State of Mato Grosso, Brazil.

\begin{tabular}{|c|c|c|c|c|c|}
\hline \multirow[t]{2}{*}{ Dogs } & \multirow[t]{2}{*}{ Age } & \multirow{2}{*}{$\begin{array}{l}\text { Clinical } \\
\text { signs }\end{array}$} & \multirow{2}{*}{$\begin{array}{c}\text { Blood smear } \\
\text { cytology }\end{array}$} & \multicolumn{2}{|c|}{ PCR results (Closest GenBank similarity) } \\
\hline & & & & Babesia primers & Hepatozoon primers \\
\hline 1 & 24 months old, female & $\begin{array}{l}\text { Lymphadenopathy, myoclonus, } \\
\text { pale mucous }\end{array}$ & Hepatozoon sp. & - & $+(100 \%$ H. canis $)$ \\
\hline 2 & 8 months old, female & $\begin{array}{l}\text { Lymphadenopathy, osteosarcoma, } \\
\text { pale mucous }\end{array}$ & Hepatozoon sp. & - & $+(100 \%$ H. canis $)$ \\
\hline 3 & 2 months old, male & $\begin{array}{l}\text { Diarrhea, vomiting, anorexia and } \\
\text { pale mucous }\end{array}$ & Babesia sp. & $+(100 \%$ B. canis vogeli $)$ & $+(100 \%$ H. canis $)$ \\
\hline 4 & 36 months old, male & Anorexia, vomiting and nasal secretion & Babesia sp. & $+(100 \%$ B. canis vogeli $)$ & - \\
\hline 5 & 144 months old, female & Polyuria and polydipsia & Babesia sp. & - & $+*$ \\
\hline 6 & 20 months old, female & Lymphadenopathy and fever & Babesia sp. & $+(100 \%$ B. canis vogeli $)$ & $+(100 \%$ H. canis $)$ \\
\hline 7 & 1 month old, male & $\begin{array}{l}\text { Diarrhea, vomiting, anorexia and } \\
\text { pale mucous }\end{array}$ & Babesia sp. & $+(100 \%$ B. canis vogeli $)$ & $+^{*}$ \\
\hline 10 & 3 months old, female & $\begin{array}{l}\text { Lymphadenopathy, diarrhea, } \\
\text { myoclonus and pale mucous }\end{array}$ & Babesia sp. & $+(100 \%$ B. canis vogeli $)$ & $+^{*}$ \\
\hline
\end{tabular}

$(-)$ = negative; $(+)$ = positive; ${ }^{*}$ DNA sequencing not performed due to low amount of amplified DNA. 
sequences of $B$. canis vogeli (AY371196; EF052632; DQ297390; AY371195; AY371194). The partial sequence (18S rRNA) generated from dog number 10 was deposited in the GenBank and assigned the nucleotide accession number JF295087. The sequences obtained from the Hepatozoon-PCR showed to be $100 \%$ identical to $H$. canis (AY461375; HM212626; GU371448; GU371447; GQ176245; FJ743476; FJ497022; FJ497021; FJ497020; EU571737; AY150067; AY471615; AF418558). The partial sequence (18S rRNA) of $H$. canis generated from dog number 2 in this study was deposited into the GenBank and assigned the nucleotide accession number JF295088. This isolate of $H$. canis was designated strain Cuiabá of $H$. canis and was stored frozen at $-86^{\circ} \mathrm{C}$ where it is available upon request. Regarding clinical signs in these infected dogs, no pathognomonic symptoms could be associated to canine infection by $H$. canis or $B$. canis vogeli.

Recently, André et al. (2010) reported H. canis in Brazilian wild carnivores, including animals from Cuiabá, but to our best knowledge there has been no previous report of $H$. canis in domestic dogs in the city of Cuiabá, State of Mato Grosso, and this is the first report confirmed by molecular biology tools. Additionally, it is described for the first time the molecular detection of $B$. canis vogeli among domestic dogs in Cuiabá.

\section{Acknowledgments}

We thank Sheila Oliveira de Souza for her technical assistance in DNA sequencing, the Conselho Nacional de Desenvolvimento Cientifico e Tecnológico for providing a grant to M.B. Labruna, the Coordenação de Aperfeiçoamento de Pessoal de Nivel Superior for providing grants to M.M. Torres, W.N.S. Campos and A.L.T. Melo and the Fundação de Amparo a Pesquisa do Estado de São Paulo for providing a grant to M.G. Spolidorio.

\section{References}

ALMEIDA. A. P. Pesquisa de Rickettsia, Ehrlichia, Anaplasma, Babesia, Hepatozoon e Leishmania em Cachorro-do-mato (Cerdocyon thous) de vida livre do Estado do Espírito Santo. 2011. 80 f. Dissertação (Mestrado Epidemiologia Experimental Aplicada)-Universidade de São Paulo, São Paulo.

ALTSCHUL, S. F. et al. Basic local alignment search tool. Journal of Molecular Biology, v. 215, n. 3, p. 403-410, 1990.
ANDRÉ, M. R. et al. Molecular detection of Hepatozoon spp. in Brazilian and exotic wild carnivores. Veterinary Parasitology, v. 173, n. 1-2, p. 134-138, 2010. PMid:20630658. http://dx.doi.org/10.1016/j. vetpar.2010.06.014

BANETH, G. et al. Genetic and antigenic evidence supports the separation of Hepatozoon canis and Hepatozoon americanum at the species level. Journal of Clinical Microbiology, v. 38, n. 3, p. 1298-1301, 2000.

FORLANO, M. et al. Diagnosis of Hepatozoon spp. in Amblyomma ovale and its experimental transmission in domestic dogs in Brazil. Veterinary Parasitology, v. 134, n. 1-2, p. 1-7, 2005. PMid:16081219. http://dx.doi.org/10.1016/j.vetpar.2005.05.066

GREENE, C. E. Infectious Diseases of The Dog and Cat. 3. ed. Sant Louis: Saunders Elsevier, 2006. 1387 p.

LABRUNA, M. B.; CAMPOS PEREIRA, M. Carrapato em cães no Brasil. Clínica Veterinária, v. 30, p. 24-32, 2001.

McCULLY, R. M. et al. Observations on naturally acquired hepatozoonosis of wild carnivores and dogs in the Republic of South Africa. Onderstepoort Journal of Veterinary Research, v. 42, n. 4, p. 117-133, 1975 .

MURATA, T. et al. First case of Hepatozoon canis infection of a dog in Japan. Journal of Veterinary Medicine Science, v. 53, n. 6, p. 1097-1099, 1991.

PALUDO, G. R. et al. Hepatozoon spp.: pathological and partial $18 \mathrm{~S}$ rRNA sequence analysis from three Brazilian dogs. Parasitology Research, v. 97, n. 2, p. 167-170, 2005. PMid:15988602. http://dx.doi. org/10.1007/s00436-005-1419-2

PASSOS, L. M. et al. First molecular detection of Babesia vogeli in dogs from Brazil. Veterinary Parasitology, v. 127, n. 1, p. 81-85, 2005. PMid:15619377. http://dx.doi.org/10.1016/j.vetpar.2004.07.028

RUBINI, A. S. et al. Molecular identification and characterization of canine Hepatozoon species from Brazil. Parasitology Research, v. 97, n. 2, p. 91-93, 2005. PMid:15948009. http://dx.doi.org/10.1007/ s00436-005-1383-x

RUBINI, A. S. et al. Acquisition and transmission of Hepatozoon canis (Apicomplexa: Hepatozoidae) by the tick Amblyomma ovale (Acari: Ixodidae). Veterinary Parasitology, v. 164, n. 2-4, p. 324-327, 2009. PMid:19501969. http://dx.doi.org/10.1016/j.vetpar.2009.05.009

SPOLIDORIO, M. G. et al. Hepatozoon canis infecting dogs in the State of Espírito Santo, southeastern Brazil. Veterinary Parasitology, v. 163, n. 4, p. 357-61, 2009. PMid:19482427. http://dx.doi.org/10.1016/j. vetpar.2009.05.002

TRAPP, S. M. et al. A. Babesia gibsoni genotype Asia in dogs from Brazil. Veterinary Parasitology, v. 141, n. 1-2, p. 177-180, 2006. 